
pan evaporation. Horticultura Brasileira 27: 059-063.

\title{
Oregano production under various water depths estimated by means of the class A pan evaporation
}

\author{
Patricia Angélica A Marques; Lineu Bernardi Filho; Ricardo B de Oliveira \\ UNOESTE-Dep ${ }^{\text {to }}$ Agronomia, Rod. Raposo Tavares, km 572, 19067-175 Presidente Prudente-SP; pmarques@ unoeste.br
}

\begin{abstract}
The purpose of this experiment was to analyze the effect of five irrigation water depths on oregano production. Oregano is a plant rich in essential oil, commonly used as seasoning in food preparation. The water depths were estimated based on the class A pan evaporation (CPE): 0 CPE (without water replacement); $25 \mathrm{CPE}, 50 \mathrm{CPE}, 75$ $\mathrm{CPE}$, and $100 \% \mathrm{CPE}$. The analyzed variables were fresh and dry weight of leaves and roots, yield, net return, and water use efficiency. The experiment was carried out in Presidente Prudente, São Paulo State, Brazil, from February to May 2006. The best results for all the studied variables were found when $100 \%$ CPE was used. A linear positive relation was observed between water increments and fresh and dry weight of both the aboveground part and roots. The use of a water depth corresponding to $100 \% \mathrm{CPE}$ resulted in the maximum productivity $\left(8,089.7 \mathrm{~kg} \mathrm{ha}^{-1}\right)$, and in the highest net annual return $\left(\mathrm{R} \$ 57,637.87 \mathrm{ha}^{-1}\right)$.
\end{abstract}

Keywords: Origanum vulgare L., evaporation, medicinal plants, yield, net profit, water use efficiency.

\section{RESUMO}

Produção de orégano com diferentes lâminas de irrigação estimadas a partir da evaporação do tanque classe $A$

Foi analisado o efeito de cinco lâminas de irrigação na produção do orégano, planta rica em óleo essencial, muito usada como tempero na preparação de alimentos. As lâminas de água foram baseadas na evaporação do tanque classe A (ECA) sendo: 0 ECA (sem reposição de água); 25 ECA; 50 ECA; 75 ECA e 100\% ECA. As variáveis analisadas foram matéria fresca e seca de folhas e raízes, produtividade, receita líquida e eficiência do uso da água. O experimento foi instalado em Presidente Prudente (SP), de fevereiro a maio de 2006. Os melhores resultados para todas as variáveis estudadas foram encontrados com a reposição de 100\% ECA. Observou-se uma relação linear positiva entre o incremento das lâminas de irrigação e as massas fresca e seca tanto da parte aérea, quanto das raízes. A aplicação da lâmina de irrigação equivalente a $100 \%$ ECA resultou na máxima produtividade observada $\left(8.089,7 \mathrm{~kg} \mathrm{ha}^{-1}\right)$ e na receita líquida anual mais alta $\left(\mathrm{R} \$ 57.637,87 \mathrm{ha}^{-1}\right)$.

Palavras-chave: Origanum vulgare L., evaporação, plantas medicinais, produtividade, renda líquida, eficiência do uso de água.

\section{(Recebido para publicação em 9 de novembro de 2007; aceito em 23 de dezembro de 2008)}

\section{(Received in November 8, 2007; accepted in December 23, 2008)}

$\mathrm{C}$ ondimental, aromatic, and medicinal plants can generate income in small farms. However, its commercialization requires high quality products and constant supplies. According to Rezende et al. (1999), due to the growth in the world population, it is essential to increase the production of high efficient food, as well as to search for alternatives in the production process.

The market interest in aromatic plants has been growing, particularly in the case of the oregano (Origanum vulgare L.). Oregano is a small plant from the family Lamiaceae, very common in the Mediterranean region (Mastro et al., 2004). Owing to the high content of essential oil, oregano is very often used as seasoning in food preparation. As a medicinal plant, it is used to treat stomachaches and as diuretic. Nowadays several uses for oregano have been investigated, as reported by Cintra \& Mancini Filho (2001) and Bernal
Gómez (2003), who studied the antioxidant effects of oregano extracts, and Clemente et al. (2003), who tested its effect as an insect repellent.

From the agronomical point of view, there is little available information on the behavior of condimental, aromatic, and medicinal plants when exposed to agricultural practices. Consequently, there are also few studies referring to effects of hydric stress on medicinal plants (Scheffer, 1992; Silva et al., 2002). Several condimental, aromatic, and medicinal plants are grown with the use of supplementary irrigation, such as oregano, chamomile, sage, and mint (Hadid et al., 2004).

Silva et al. (2002) studied the effect of hydric stress over the content and chemical composition of the essential oil, as well as over plant growth of Melaleuca alternifolia Cheel (Myrtaceae). Each treatment consisted of four water depths and hydric stresses.
Severe hydric deficiency reduced growth and plant fresh and dry weight. Carvalho et al. (2003) studied the effect of soil water availability on mugwort growth with distinct water replacement levels. A 22.5\% reduction in fresh weight was observed in plants grown with 50\% water replacement in relation to those grown with a water replacement of $90 \%$. In their study, Hadid et al. (2004) observed that oregano, when irrigated, presented economic revenues higher than those obtained with main crops, yielding 24 times more economic return than wheat when grown in Syria arid regions. Upon supplementary irrigation, oregano productivity reached $7000 \mathrm{~kg}$ ha $^{-1}$.

Climate is one of the most important factors in determining the volume of water lost by crop evapotranspiration. Besides the climatic factors, the evapotranspiration is also influenced by the crop itself. One of the methods used 


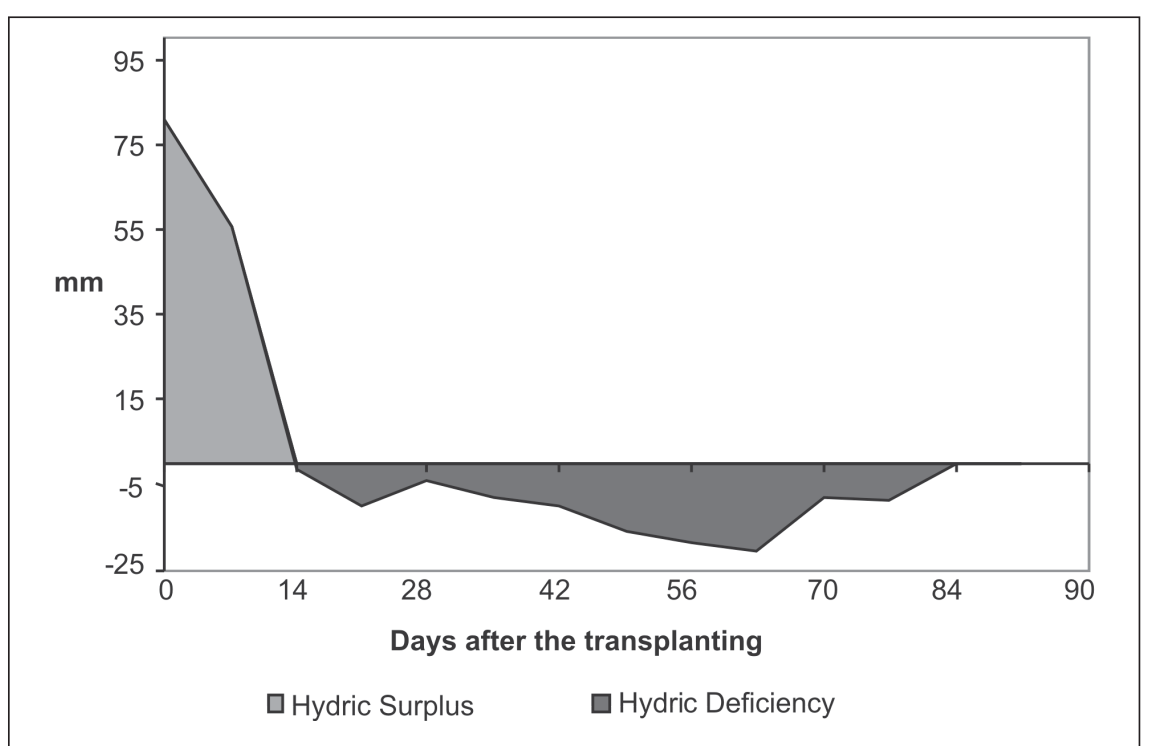

Figure 1. Water balance from February 24 to May 242006 (balanço hídrico de 24 de fevereiro a 24 de maio de 2006). Presidente Prudente, UNOESTE, 2006.

to estimate the evapotranspiration (ETo) is the class A pan, in which the integrated effects of solar radiation, wind, temperature, and relative humidity that act over the crop are measure as function of the evaporation these factors caused over a water free surface (Doorenbos \& Pruitt, 1984). The A class pan is easy to manage and of relatively low cost, and provides satisfactory estimates of crop hydric demands (Volpe \& ChurataMasca, 1998).

The objective of this experiment was to define the most adequate irrigation management for oregano production by means of applying five irrigation water depths to the soil, based on the class A pan evaporation (CPE).

\section{MATERIAL AND METHODS}

The field experiment was carried out at the State Technical College Prof. Dr. Antônio Eufrásio de Toledo, from February 24 to May 24, 2006, in Presidente Prudente, São Paulo State (22 $2^{\circ} 07^{\prime} 04^{\prime \prime} \mathrm{S} ; 51^{\circ} 22^{\prime} 05^{\prime \prime} \mathrm{W}$; $435.5 \mathrm{~m}$ osl). Climate is Aw mesothermal by the Köppen classification, with hot summers and dry winters. The soil is classified as Haplic Lixisol, with sandy texture (EMBRAPA, 1999). The soil chemical analysis was carried out according to Raij et al. (2001) and revealed $\mathrm{CaCl}_{2}=$ $6.3 \mathrm{pH}$; organic weight $=5 \mathrm{~g} \mathrm{dm}^{-3} ; \mathrm{P}=24$ $\mathrm{mg} \mathrm{dm}{ }^{-3} ; \mathrm{K}=2.2 \mathrm{mmol}_{\mathrm{c}} \mathrm{dm}^{-3} ; \mathrm{Ca}=19$ $\mathrm{mmol}_{\mathrm{c}} \mathrm{dm}^{-3} ; \mathrm{Mg}=14 \mathrm{mmol}_{\mathrm{c}} \mathrm{dm}^{-3} ; \mathrm{Al}=0$ $\mathrm{mmol}_{\mathrm{c}}^{\mathrm{c}} \mathrm{dm}^{-3} ; \mathrm{SO}^{-2}{ }_{4}=8 \mathrm{mmol}_{\mathrm{c}} \mathrm{dm}^{-3} ; \mathrm{SB}=$ $35 \mathrm{mmol}_{\mathrm{c}} \mathrm{dm}^{-3} ; \mathrm{CEC}=51 \mathrm{mmol}_{\mathrm{c}} \mathrm{dm}^{-3} \mathrm{e} \mathrm{V}$ $=69 \%$. Neither fertilization, nor liming were used, once the experimental area is frequently used for growing vegetable crops, and the soil shows a V\% value near to $70 \%$ and adequate nutrient contents (Raij et al., 1996). According to Côrrea Júnior et al. (1991) and Oliveira Júnior et al. (2006) there has been very little information on the nutritional requirements of medicinal plants, mainly in Brazil.

Oregano plantlets were obtained by planting cuttings on 120 -cell polypropylene trays, kept in greenhouse for 30 days (from January 24 to February 24). The experiment was carried out in a completely randomized design. Treatments corresponded to five water depths based on the class A pan evaporation (CPE), as follows: T1 (without water replacement) $=0 \% \mathrm{CPE}$, $\mathrm{T} 2=25 \% \mathrm{CPE}, \mathrm{T} 3=50 \% \mathrm{CPE}, \mathrm{T} 4=75 \%$ $\mathrm{CPE}$ and $\mathrm{T} 5=100 \% \mathrm{CPE}$, with five replications. The soil was harrowed and, then, $2.0 \times 1.4 \mathrm{~m}$ seed-beds were manually raised, resulting in 25 plots of $2.8 \mathrm{~m}^{2}$. Experimental plots were physically separated by screen boards to prevent from water cross-interference. Each plot consisted of 15 plants, in which only the central row was taken as useful area. Spacing between plants was $0.6 \mathrm{~m} \times 0.3$ m (Ministério da Agricultura, Pecuária e
Abastecimento, 2006).

The irrigation water depths (equation 1) were estimated as function of the daily readings on the class $\mathrm{A}$ pans at the UNOESTE meteorological station, in Presidente Prudente. A manual water can, graded with a $500 \mathrm{~mL}$ scale, was used. The irrigation was applied daily, at the end of the afternoon, in a uniform way, in order to have a good control of the water depths in each seed-bed.

$\mathrm{hi}=\mathrm{ECA} \cdot \mathrm{kp} \cdot \mathrm{kc} \cdot \mathrm{S}$, equation (1), where: hi = irrigation volume applied (L); $\mathrm{CPE}=$ class A pan evaporation (mm); $\mathrm{Kp}=$ class A pan coefficient; $\mathrm{Kc}=$ crop coefficient; and $\mathrm{S}=$ seed-bed area $(2.8$ $\mathrm{m}^{2}$ ). Kp was considered as 0.80 (ordinary value found for the experiment site), while $\mathrm{Kc}$ was considered as 1.0, which is the average $\mathrm{Kc}$ recommended for spearmint (Allen et al., 1998).

Throughout the crop cycle, cultural practices consisted of manual hoeing and control against ant infestation using baits. Harvest took place on May 24, 2006, at around 9:00 am. Roots were obtained by digging out the whole soil clod explored by plants, up to $30 \mathrm{~cm}$ of depth. Fresh leaves and roots were weighed on an analytic scale to obtain the fresh weight per plant of both the aboveground part (FWA) and roots (FWR). Following, leaves and roots were dried until constant weight in an oven at $45^{\circ} \mathrm{C}$, which is the temperature recommended by the Ministry of Agriculture, Livestock, and Food Supply (2006) for drying aromatic plants, in order to reduce losses due to volatilization. The dry weight of both the aboveground part (DWA) and roots (DWR) were determined using an analytical scale. Data were submitted to analyses of variance. Regression curves were computed using the software SISVAR 4.6.

To evaluate oregano yield, a standard crop was considered as having a stand of 50.000 plants per hectare, planted in seed-beds as recommended by the Ministry of Agriculture, Livestock, and Food Supply (2006). To analyze the irrigation viability, the oregano production cost in a dry-farming system was taken as BRL\$2,600.00 per hectare (Ministério da Agricultura, Pecuária e Abastecimento, 2006); the oregano sales 


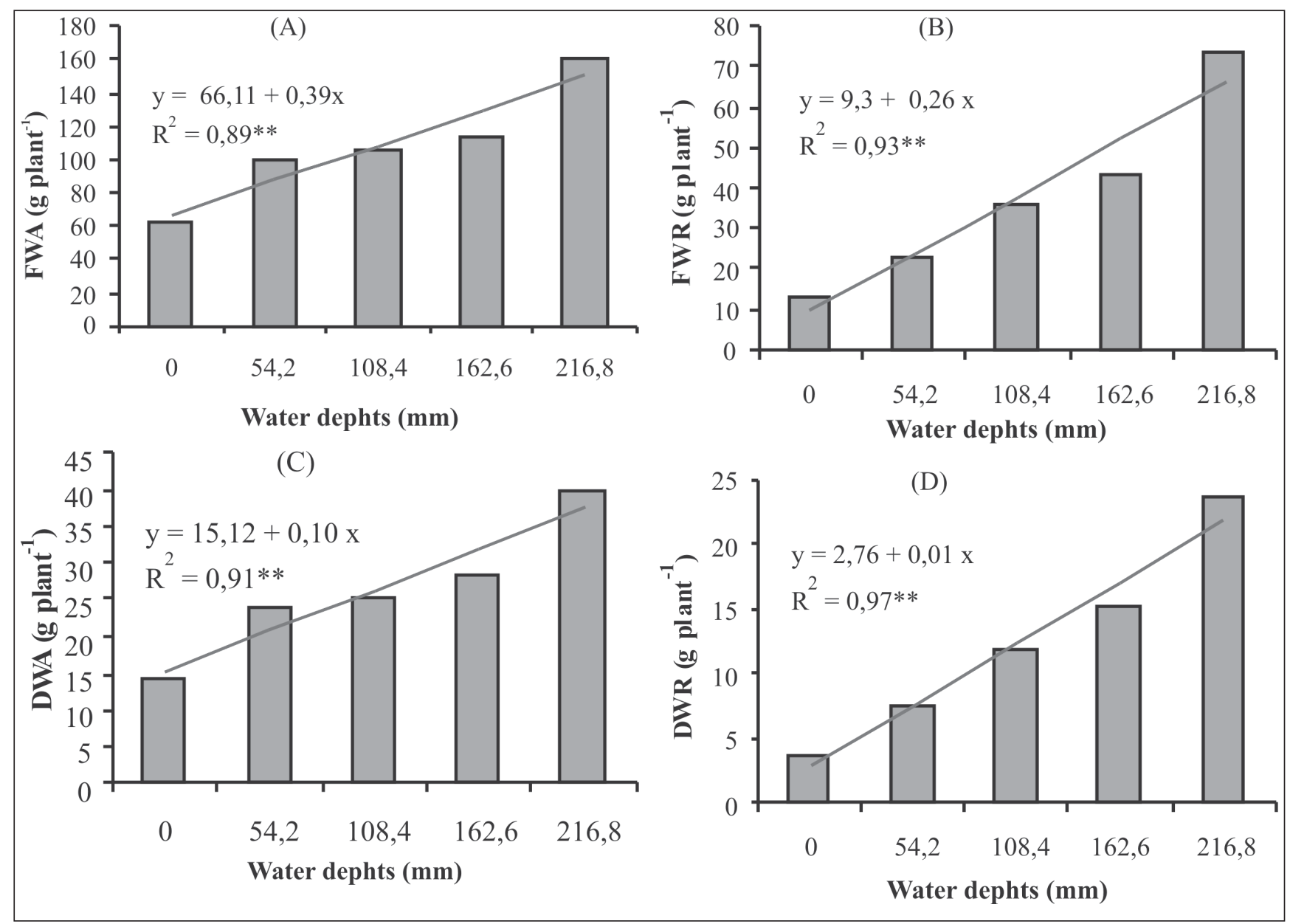

Figure 2. Fresh weight of the aboveground part (A) and roots (B) and dry weight of the aboveground part (C) and roots (D) of oregano as affected by distinct irrigation depths (matéria fresca da parte aérea (A) e das raízes (B) e material seca dap arte aérea (C) e das raízes (d) em função de diferentes laminas de irrigação). Presidente Prudente, UNOESTE, 2006.

price was assumed as BRL $\$ 9.77$ per $\mathrm{kg}$ (ABH, 2007), equivalent to $80 \%$ of the price in the wholesale market, due to the discounts that occur from harvest to resale at São Paulo General Wholesale Market (CEAGESP); the annual irrigation cost for microsprinkling was considered as BRL\$ 813.73 per hectare, which corresponds to the price of acquiring the equipment (BRL \$ 5,000.00 per hectare), a 10-year useful life, interest rate of $10 \%$ per year, and a water cost of BRL $\$ 0.01$ per m $^{3}$ of water applied (Marques \& Coelho, 2003; Blanco et al., 2004; Marques et al., 2006). The calculation attended the computational model used for economic risk analyses in irrigated crops (Marques $\&$ Frizzone, 2005). This model computes returns and costs in annual terms to adjust the results of irrigation viability.

Considering one crop cycle a year, yield values (equation 2) were used to calculate the annual gross return by equation 3 (Frizzone, 2002), the annual net return by equation 4 (Marques \& Frizzone, 2005; Marques et al. 2006), and the water use efficiency use (WUE) by equation 5 (Koetz et al., 2006).

$$
\begin{aligned}
& Y=F W A .50 .000 \\
& G I=Y \cdot \text { Price } \\
& N I=G I-[(P C \cdot Y)+I C+W C] \\
& W U E=\frac{F W A}{(P+W D)}
\end{aligned}
$$

where: $\mathrm{Y}$ stands for the oregano yield $\left(\mathrm{kg} \mathrm{ha}^{-1}\right.$ year $\left.^{-1}\right)$; FWA stands for the fresh weight of the aboveground part (kg); GI stands for the annual gross return $\left(\mathrm{BRL} \$\right.$ ha $^{-1}$ year $\left.^{-1}\right)$; Price stands for the price paid to the producer $\left(\mathrm{BRL} \$ \mathrm{~kg}^{-1}\right)$; NI stands for the annual net return $\left(\mathrm{BRL} \$ \mathrm{ha}^{-1}\right.$ year $\left.^{-1}\right)$; PC stands for the oregano production cost without the irrigation costs (BRL $\left.\$ \mathrm{~kg}^{-1}\right)$; IC stands for the annual irrigation cost (BRL\$ ha- ${ }^{-1}$ ano $\left.^{-1}\right)$; WC stands for the water cost (BRL\$ 0,01 o $\mathrm{m}^{3}$ ); WUE is the water use efficiency $\left(\mathrm{kg} \mathrm{ha}^{-1} \mathrm{~mm}^{-1}\right)$; $\mathrm{P}$ stands for the effective precipitation occurred in the period $(\mathrm{mm})$ and WD is the total irrigation water depth applied in the period $(\mathrm{mm})$.

The water balance was used to control the irrigation. The water balance is an adaptation of the sequential climatologic water balance that allows tracking water storage in the soil in real time. For the weekly water balance, an available water content (AWC) of 100 $\mathrm{mm}$ was considered, and the capillary rise and precipitations below $10 \mathrm{~mm}$ were discarded, as recommended by Pereira et al. (2002).

\section{RESULTS AND DISCUSSION}

A $96 \mathrm{~mm}$ pluvial precipitation was observed in the period studied, with peaks of $13 \mathrm{~mm}$ on the $13^{\text {th }}$ and $14^{\text {th }}$ days after the transplant (DAT), and $10 \mathrm{~mm}$ in 


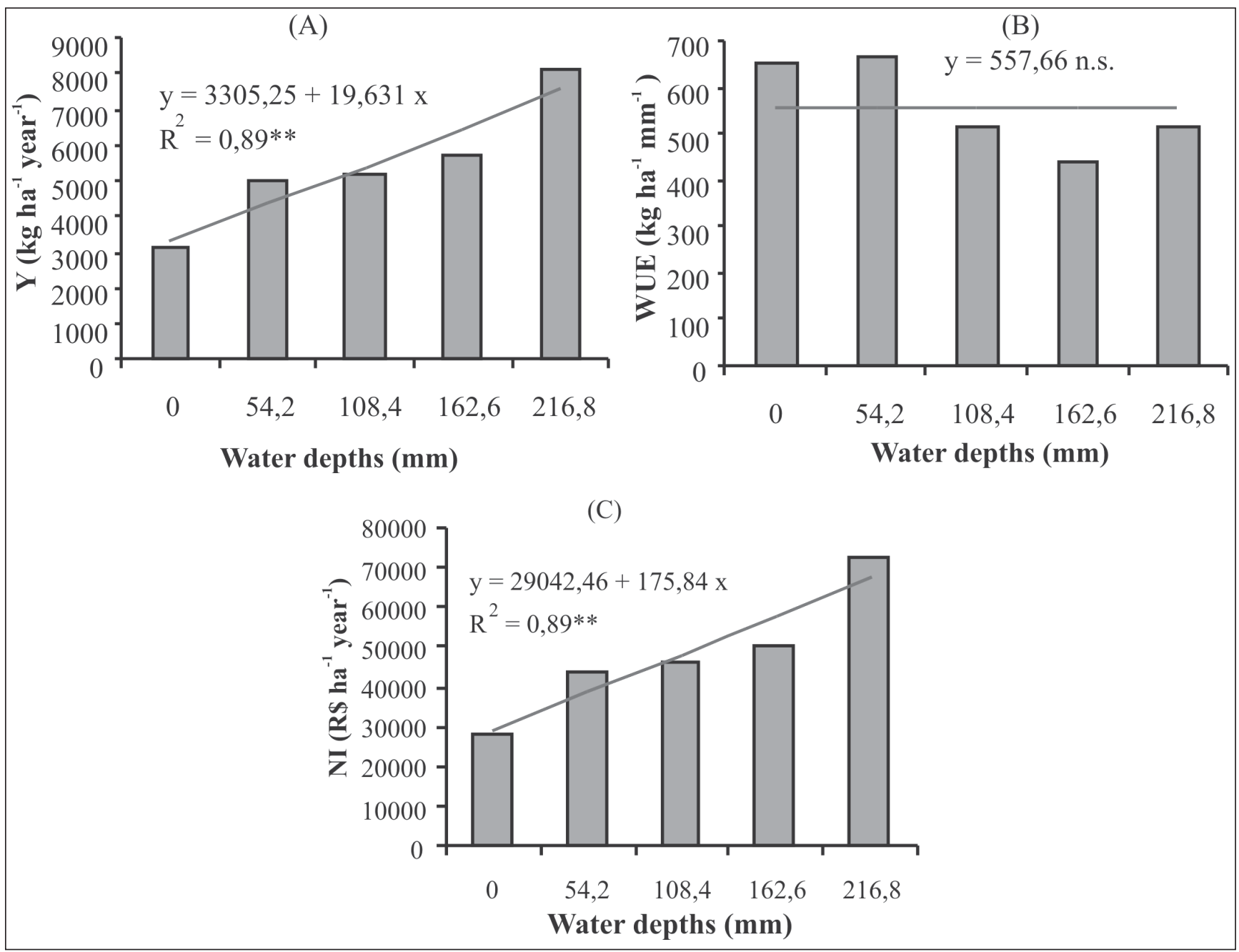

Picture 3. Yield (A), water use efficiency (B), and net annual return (C) of oregano as affected by distinct irrigation depths (produtividade (A), eficiência no uso da água (B) e receita líquida anual (c) de orégano em função de diferentes lâminas de irrigação). Presidente Prudente, UNOESTE, 2006.

the $64^{\text {th }}$ DAT. The weekly hydric balance referring to this period (Figure 1) demonstrates the hydric surplus at the beginning of the cycle, followed by the hydric deficit until the end of the oregano cycle. The total irrigation depth applied for each treatment was $0 \mathrm{~mm}$ for $\mathrm{T} 1 ; 54.2$ $\mathrm{mm}$ for $\mathrm{T} 2$ (25\% CPE); $108.4 \mathrm{~mm}$ for $\mathrm{T} 3$ (50\% CPE); $162.6 \mathrm{~mm}$ for T4 (75\% CPE), and $216.8 \mathrm{~mm}$ for $\mathrm{T} 5$ (100\% CPE).

Treatments significantly differed from one another (Figure 2). A positive linear relation was observed between increments on the water depth replacement and the fresh weight of the both the aboveground part (FWA) and roots (FWR), as well as the dry weight of the aboveground part (DWA) and roots (DWR). According to Pandey et al. (1984), the dry weight results from the crop integrated response to the stress, from the emergence to the physiologic maturity. Thus, it shows the accumulated deficiency effect throughout the crop cycle: the hydric deficiency interrupts the growth process, changing the fresh weight accumulation and accelerating catabolic processes (Kudrev, 1994).

The maximum FWA was $161.8 \mathrm{~g}$ plant $^{-1}$, obtained with the irrigation depth of $216.82 \mathrm{~mm}(100 \% \mathrm{CPE})$ during the whole cycle, while the check treatment (0\% CPE) presented $62.5 \mathrm{~g}_{\text {plant }}{ }^{-1}$ of FWA. In percentage terms, the absence of water replacement reduced the FWA in $61.3 \%$ in relation to an irrigation depth equivalent to $100 \% \mathrm{CPE}$. Considering the DWA, the absence of water replacement induced a $64.5 \%$ drop in relation to the replacement of $100 \% \mathrm{CPE}$. The same tendency of production drops in association with lower levels of water replacement was found in Silva et al. (2002) for Melaleuca alternifólia, Carvalho et al. (2003) and Carvalho et al. (2005), for mugwort, and by Silber $e t$ al. (2006) for Leucadendron, an ornamental plant. For Bergonci et al. (2000) this linear response happens due to the faster replacement of the water lost at the moments of higher transpiration in plants with adequate hydric availability (100\% CPE) in relation to those in which there was hydric limitation.

The hydric deficiency showed direct influence in the oregano root system development (FWR and DWR). Farias et al. (2003) observed the same behavior in Chrysanthemum under different water tensions in the substrate, once the plants under hydric deficiency tend to 
grow less than those properly irrigated. The reduction in fresh and dry weight of root from a water replacement level corresponding to $100 \% \mathrm{CPE}$ to $0 \% \mathrm{CPE}$ was 82.9 and $82.6 \%$, respectively. According to Bergonci et al. (2000) and Silber et al. (2006), a soil with low water content will have its resistance to water flow to roots increased due to the low hydraulic conductivity; as the soil gets dry, the contact between soil and roots reduces and restrains the plant water replacement. Consequently, in non severe deficit situations, as in treatments with 50 and $75 \% \mathrm{CPE}$ water replacement, the root system explores the soil in spots where there is still available water (Morison \& Gifford, 1984; Silber et al., 2006).

When yield was evaluated (Figure $3 \mathrm{~A})$, the replacement water depth equivalent to $100 \% \mathrm{CPE}$ also resulted in the highest numbers, with a maximum of $8,089.7 \mathrm{~kg} \mathrm{ha}^{-1}$. On the other hand, the water use efficiency (Figure 3B) was not significantly influenced by the variation in the irrigation depth. In the study of the irrigation economic availability based on the annual net return (Figure $3 \mathrm{C}$ ), it was noticed that the replacement water depth of $100 \% \mathrm{CPE}$ resulted in the highest annual net return (BRL\$ 57,637.87). Hadid et al. (2004) also reached the best yield results and net return for oregano with an irrigation water depth corresponding to $100 \% \mathrm{CPE}$.

Altogether, the variation in the irrigation water depth influenced oregano crop development. A positive linear relation between increments on the replacement water depth and both oregano yield and net return was noticed. Consequently, the use of an irrigation water depth correspondent to $100 \%$ of the class A pan evaporation must be considered as the adequate water management for growing oregano at Presidente Prudente region.

\section{REFERENCES}

ABH - Associação Brasileira de Horticultura. 2007, 02 de fevereiro. Cotações de produtos agrícolas do dia 31 de janeiro de 2007. Disponível em http:// www.abhorticultura.com.br/Cotacoes/ Default.asp?lb=1

ALLEN RG; PEREIRA LS; RAES D; SMITH M. 1998. Crop Evapotranspiration. Guidelines for Computing Crop Water Requirements. Rome: FAO. 300p. Irrigation and Drainage. (Paper, 56)
BERGONCI JI; BERGAMASCHI H; BERLATO MA; SANTOS AO. 2000. Potencial da água na folha como um indicador de déficit hídrico em milho. Pesquisa Agropecuária Brasileira 35: 1531-1540.

BERNAL GÓMEZ MED. 2003. Modulação da composição de ácidos graxos poliinsaturados ômega 3 de ovos e tecidos de galinhas poedeiras, através da dieta. I. Estabilidade oxidativa. São Paulo: USP FCF. 129p. (Tese doutorado)

BLANCO FF; MACHADO CC; COELHO RD; FOLEGATTTI MV. 2004. Viabilidade econômica da irrigação da manga para o Estado de São Paulo. Revista Brasileira de Engenharia Agrícola e Ambiental 8: 153-159.

CARVALHO LM; CASALI VWD; SOUZA MA; BARBOSA CA; CECON PR. 2005. Crescimento, teor de partenolídeo e de prolina em plantas de tanacetum parthenium (L.) Schultz-Bip crescidas em substrato com diferentes teores de umidade. Acta Scientiarum Agronomy 27: 151-157.

CARVALHO LM; CASALI VWD; SOUZA MA; CECON PR. 2003. Disponibilidade de água no solo e crescimento de artemísia. Horticultura Brasileira 21: 726-730.

CINTRA RMG; MANCINI FILHO J. 2001. Efeito Antioxidante de especiarias: avaliação e comparação de métodos in vitro e in vivo. Nutrire 22: 49-62.

CLEMENTE S; MAREGGIANI G; BROUSSALI IA; MARTIN SV; FERRARO OG. 2003 Insecticidal effects of Lamiaceae species against stored products insects Boletin de Sanidad Vegetal Plagas 29: 1-8.

CÔRREA JUNIOR C; MING LC; SCHEFFER MC. 1991. Cultivo de plantas medicinais, condimentares e aromáticas. Curitiba: EMATER-PR. $151 \mathrm{p}$.

DOORENBOS J, PRUITT WO. 1984. Guidelines for predicting crop water requirements. Rome: FAO. 144p. Irrigation and Drainage. (Paper, 24).

EMBRAPA 1999. Sistema brasileiro de classificação de solos. Brasília: EMBRAPASPI, EMBRAPA-CNPS, 412p.

FARIAS MF; SAAD JCC; VILLAS BÔAS RL. 2003. Qualidade comercial do crisântemo de vaso em ambiente protegido, cultivar puritan, irrigado sob diferentes tensões de água no substrato. Irriga 8: 160-167.

FRIZZONE JA. 2002. Análise de decisão de investimento em irrigação. Piracicaba: ESALQ/USP. 394p.

HADID AA; BATANOUNY KH; JABARINE AS; KADER AA. 2004 Proposal for Expanding the Crop Mandate of ICARDA to Include Horticultural Crops. Syria: ICARDA. 53p.

KOETZ M; COELHO G; COSTA CC; LIMA EP; SOUZA RJ. 2006. Efeito de doses de potássio e da freqüência de irrigação na produção da alface-americana em ambiente protegido. Engenharia Agrícola 26: 730-737.

KUDREV T. 1994 Água: vida das plantas. São Paulo: Ícone 178p.

MARQUES PAA; COELHO RD. 2003. Estudo da viabilidade econômica da irrigação da pupunheira (Bactris Gasipaes H.B.K.) para Ilha Solteira - SP, Brasil. Ciência Rural 33: 291-297.
MARQUES PAA; FRIZZONE JA. 2005. Modelo computacional para determinação do risco econômico em culturas irrigadas. Acta Scientiarum 27: 725-733.

MARQUES PAA; MARQUES TA; FRIZZONE JA. 2006. Viabilidade econômica sob condições de risco para a irrigação da canade-açúcar na região de Piracicaba-SP. Revista Irriga 11: 55-65.

MASTRO G; RUTA G; MARZI V. 2004. Agronomic and technological assessment of oregano (Origanum vulgare ssp.) Biotypes. Acta Horticulturae 629: 355-363.

MINISTÉRIO DA AGRICULTURA, ABASTECIMENTO E PECUÁRIA. 2006. Boas Práticas Agrícolas (BPA) de plantas medicinais, aromáticas e condimentares. Brasília: MAPA/SDC. 48p. (Plantas Medicinais \& Orientações Gerais para o Cultivo, 1)

MORISON JIL; GIFFORD RM. 1984. Plant Growth and Water Use With Limited Water Supply in High $\mathrm{CO}_{2}$ Concentrations. II. Plant Dry Weight, Partitioning and Water Use Efficiency. Australian Journal of Plant Physiology 11: 375-384.

OLIVEIRA JÚNIOR AC; FAQUIN V; PINTO JEBP. 2006. Efeitos de calagem e adubação no crescimento e nutrição de arnica. Horticultura Brasileira 24: 347-351.

PANDEY RK; HERRERA WA; PENDLETON JW. 1984. Drought response of grain legumes under irrigation gradient. II. Plant water status and canopy temperature. Agronomy Journal 76: 553-557.

PEREIRA AR; ANGELOCCI LR; SENTELHAS PC. 2002. Agrometeorologia: fundamentos e aplicações práticas. Guaíba: Agropecuária $478 \mathrm{p}$.

RAIJ B van; CANTARELLA H; GUAGGIO JA; FURLANI AMC. 1996. Recomendações de adubação e calagem para o Estado de São Paulo. $2^{\text {a ed. }}$ Campinas: Instituto Agronômico \& Fundação IAC, 285p. (Boletim Técnico, 100)

RAIJ B. van; ANDRADE JC; CANTARELLA H; QUAGGIO JA. 2001. Análise química para avaliação de fertilidade de solos tropicais. Campinas: Instituto Agronômico, 285p.

REZENDE R; CARDOSO CO; GONÇALVES ACA; PERES FC; FRIZZONE JA; FOLEGATTI MV. 1999. Viabilidade econômica da irrigação suplementar na cultura de citros na região noroeste do Estado do Paraná. Acta Scientiarum 21:591-598.

SCHEFFER MC. 1992. Roteiro para estudo de aspectos agronômicos das plantas medicinais selecionadas pela fitoterapia do SUS-PR/ CEMEPAR. SOB Informa 11: 29-31.

SILBER A; LEVI M; COHEN M; DAVID N; SHTAYNMETZ Y; ASSOULINE S. 2006. Response of Leucadendron 'Safari Sunset' to irrigation and fertilisation levels. Journal of Horticultural Science and Biotechnology 81: 355-364.

SILVA SRS; DEMUNER AJ; BARBOSA LCA; CASALI VWD; NASCIMENTO EA; PINHEIRO AL 2002. Efeito do estresse hídrico sobre características de crescimento e a produção de óleo essencial de Melaleuca alternifolia Cheel. Acta Scientiarum 24: 1363-1368.

VOLPE CA; CHURATA-MASCA MGC. 1998. Manejo da irrigação em hortaliças: método do Tanque Classe A. Jaboticabal: FUNEP. 19p. 